\title{
PASSIVE LEADERSHIP AND ITS OUTCOMES IN PUBLIC SECTOR ORGANIZATIONS; MEDIATING ROLE OF WORKPLACE INCIVILITY
}

\author{
AYESHA AKHTAR \\ Capital University of Science and Technology, Islamabad, Pakistan
}

\begin{abstract}
The objective of the study was to examine the relationship between passive leadership and its outcomes in public sector organizations, with mediating role of workplace incivility. Data was collected from 245 government sector employees of Pakistan. SPSS was used to analyze data. Mediation analysis was carried out as per Preacher and Hayes (2008) bootstrapping method. Results indicate that both burnout and interpersonal conflict are not the direct outcomes of passive leadership; however, work place incivility is fully mediating the relationship between passive leadership and its outcomes that includes burnout and interpersonal conflict.
\end{abstract}

\section{INTRODUCTION}

The extant literature on leadership mainly focuses on its positive affects while the negative type of leadership has generally been ignored by researchers (Goldman, 2006). Positive aspect of leadership like transformational leadership (Krishnan \& Arora, 2008; Gooty, Gavin, Johnson, Frazier \& Snow, 2009) transactional leadership (Jung \& Avolio, 2000) authentic leadership (Avolio \& Gardner, 2005) and charismatic leadership (Shamir, House \& Arthur, 1993) have extensively been studied. The negativity associated with leadership needs further clarification.

Passive leadership is considered a type of leadership which comprises of management by exception and laissez faire leadership (Bass \& Avolio, 2004). This is considered as a destructive type of leadership, causing more stress for employees (Chenevert, Vandenberghe, Doucet, \& Ayed, 2013), burnout (Hetland, Sandal, \& Johnsen, 2007), interpersonal conflict (Doucet, Poitras, \& Chenevert, 2009), bullying, abuse, deviant behavior, counterproductive behavior, corruption, undermining, and theft (Einarsen, Aasland, \& Skogstad, 2007).

Passive leadership can result in various negative organizational outcomes; however, the mechanism through which these outcomes are related is generally missing in literature. This study proposes the mediating mechanism of workplace incivility for the above mentioned outcomes to be related to passive leadership. Work place incivility include actions such as using undignified language, making disguised threats, gossiping, ignoring the request of coworker, sending naming emails or otherwise signifying disrespect for others in the workplace (Andersson \&
Pearson, 1999).

Social exchange theory (Gouldner, 1960; Homans, 1958; Thibault \& Kelley, 1959) has supported to explain this mediating mechanism. Social exchange in the organization exists in the form of psychological contract. The perceived expectations on part of the employees include a supportive and caring behavior by the leader (Eisenberger, Huntington, Hutchison, \& Sowa, 1986). When leader is passive, we believe it constitutes breach of psychological contract and as per social exchange theory, employees engage in workplace incivility which, in turn, results in burnout and interpersonal conflict.

Apart from above literature gap, one finds that there are very few empirical studies of leadership in public sector organizations (Wart, 2003). Organizations across the public sector are facing enormous challenges due to their ineffective leadership (Alimo \& Alban, 2004). Leadership in public sector organizations is considerably different in requisites of market forces and exposure to legislation, legislatures, and civil service rules (Hooijberg \& Choi, 2001). Furthermore, public organizations show less tolerance for mistakes of leaders, foibles, and structural challenges, their skepticism and uncertainty have grown (Yankelovich, 1991).

As competition among organizations has intensified in the new global economy, even among public sector organizations, the range of skills necessary for leaders has grown (Bass, 1985). Therefore, leadership is critical to organizational outcomes in the public sector (Moynihan \& Ingraham, 2004). However, we find almost no study about negative type of leadership in public sector organizations. This omission is serious as public sector organizations, especially in underdeveloped countries, are criticized for 
negative behaviors of leaders.

Another omission in extant literature seems to be the limited focus of the studies in public sector organizations of developing countries. This study not only addresses the issue of passive leadership in the less researched context, but is probably among a very few studies of its kind which is focusing public sector organizations of Pakistan. There are around many public sector employees in Pakistan. So, our study has addressed the issue of public sector employees of this region.

\section{REVIEW OF LITERATURE}

\section{Passive Leadership and Burnout}

"Burnout is a metaphor that is commonly used to describe a state of mental weariness" (Schaufeli $\&$ Bakker, 2004). It occurs in response to the chronic emotional strain in individuals who deal extensively with other human beings, especially when these individuals are having problems of their own (Maslach \& Jackson, 1981). Maslach, Schaufeli, and Leiter (2001) described burnout as a syndrome that consist of three elements; namely, emotional exhaustion, depersonalization and professional accomplishment having harmful and damaging effects on both the employee and its organization.

Previous research suggests some of the antecedents of burnout, like intrinsic motivation, role ambiguity, role conflict (Low, Cravens, Grant \& Moncrief, 2001), jobfocused emotional labor, employee focused emotional labor (Brotheridge \& Grandey, 2002), low self-esteem, feelings of inadequacy, obsessive worry, passivity, social anxiety, and withdrawal from others (McCranie \& Brandsma, 1988). One other factor is the behavior of the leader, which is a key determinant of burnout that has progressively gotten attention from the scientific society (Bass, 1991; Gilbreath \& Benson, 2004). In particular, there exists considerable research which suggests that passive leadership is positively associated with burnout (Kanste, Miettunen, \& Kyngas, 2007; Lee \& Ashforth, 1996; Schaufeli \& Enzmann, 1998; Sosik \& Godshalk, 2000; Gill, Flaschner \& Shachar, 2006; Malloy \& Penprase, 2010; Corrigan, Diwan, Campion, \& Rashid, 2002).

Passive leaders represent a non-transactional kind of leadership style in which necessary decisions are not made, actions are delayed, leadership responsibilities are ignored, and authority is unused; a leader displaying this form of non-leadership is perceived as not caring at all about others' issues (Hamidifar, 2010). Passive or avoidance leadership suggests a disconnected and detached style of leadership; those adopting this style are prone to display the symptoms of burnout (Eid,
Johnsen, Bartone, \& Nissestad, 2008). The innate aspect of passive leadership is unsuccessful in clarifying expectations (Avolio \& Bass, 1995); thus, it is rational to hypothesize that:

\section{Hypothesis 1. Passive leadership is positively related to burnout.}

\section{Mediating role of Workplace Incivility between Passive Leadership and Burnout}

Incivility involves rudeness, impoliteness and disregard for others, breach of norm for respect and esteem in interpersonal relationships (Brown \& Levinson, 1987; Morris, 1996). Examples of incivility in the workplace entails responding the call with a "yeah", avoiding to say thanks or please, use of voice responses to screen calls, leave a half mug of tea behind to avoid having to brew the next pot, to stand over the chair of fellow beings that are engaged in a telephone talk, dropping trash on the ground or floor and leave it for the maintenance person to clean up, and talking loudly on the phone about personal matters (Martin, 1996), sarcasm, disparaging and pained tones and remarks, aggressive stares, and the "silent treatment." (Andersson \& Pearson, 1999).

Some of the precursors of workplace incivility in existing research includes affective states, workplace adaptation (Reio \& Ghosh, 2009), influence (power of job/boss), lack of assertiveness, personality, and response to anger (Bartlett, Bartlett \& Reio, 2008). Organizations must identify the underlying antecedents that lead to a rise in incivility in order to reduce its occurrence (Roberts, Scherer \& Bowyer, 2011). Leadership style exhibited by managers represents an important factor that may impact workplace incivility. In the absence of a proactive leader, workplaces may become too informal and lack clear norms to help shape appropriate behavior (Andersson \& Pearson, 1999). For this reason, incivility, especially, will likely to occur in workplaces with passive managers (Harold \& Holtz, 2014).

The harmful effects of workplace incivility have been extensively tested by practitioners (e.g., Moyer, 2008; Yeung \& Griffin, 2008). A number of studies recognized that incivility is related to harmful individual outcomes that encompass job dissatisfaction, career, mental and physical health issues, lack of organizational commitment, job withdrawal, absenteeism, low morale, and stress (Thomas \& Lankau, 2009). Cortina, Magley, Williams, and Langhout (2001) found that uncivil behaviors on daily basis and routine hassles induce stress that spoils an individual's well-being over time. Uncivil behavior effects on individual's mood and psychological well-being (Pearson, Andersson \& Wegner, 2001). Miller, Reesor, McCarrey, and Leikin (1995) found 
that workplace violence or incivility affects selfperception of a person, potentially resulting in feelings of powerlessness and burnout.

Based on above arguments, we hypothesize that:

\section{Hypothesis 2. Workplace incivility mediates the relationship between passive leadership and burnout.}

\section{Passive Leadership and Interpersonal Conflict}

Conflict is inherent and inbuilt in all social life. It occurs when an individual or a group feels negatively affected by another individual or group (Wall \& Callister 1995). Conflict has been identified as intrapersonal or interpersonal. Rahim, Garrett, and Buntzman (1992) characterized interpersonal conflict as "incompatibilities, disagreements, or differences between two or more persons". Interestingly, it is noted that interpersonal conflict is related to many commonly cited issues in organizations (Friedman, Tidd, Currall, \& Tsai, 2000; Berki \& Hartwick, 2001; Oetzel \& Ting-Toomey, 2003; Ting-Toomey \& Takai, 2006).

Prior studies have identified some of the sources of interpersonal conflict that includes a demanding boss, inconsistency between word and deed, and in-group favoritism (Leung, 2008). Generally, "conflict arises by escalating spirals of manipulation, threat and coercion, avoidance spirals, retaliation, inflexibility and rigidity, a competitive pattern of dominance and subordination, and demeaning and degrading verbal and nonverbal communication" (Greeff \& de Bruyne, 2000, p. 322). One of the main sources of interpersonal conflict are leaders who "refuse to take sides in a dispute, are disorganized in dealing with priorities, and talk about getting down to work, but never really do" (Bass, 2008, p. 143), and leaders who avoid conflict by suppressing discussions and dissenting opinions are not valued; this avoiding behavior will facilitate conflict culture (Gelfand, Leslie, Keller \& Dreu, 2012).

A lack of adequate leadership create frustration and stress within the workgroup, which may also result in interpersonal stress and rising conflict levels (Einarsen, 1999). Kelloway Sivanathan, Francis and Barling, (2005) stated that destructive leadership behaviors are sources of workplace stress, which may lead to destructive in-group behaviors, such as isolating and excluding coworkers. . When the superior has give up his responsibilities, result would be the higher level of conflicts between coworkers and other employees (Bass \& Stogdill, 1990).

Hence, the notion that destructive leadership may be a precursor of interpersonal conflicts among coworkers seems reasonable.
From the above literature one can say that

\section{Hypothesis 3. Passive leadership is positively related to interpersonal conflict}

\section{Mediating role of Workplace Incivility between Passive Leadership and Interpersonal Conflict}

Incivility is a serious and prevalent workplace problem (Pearson et al., 2001; Pearson \& Porath, 2004, 2005). It includes answering the telephone in an impolite manner, talking negatively about another employee, and sending a rude e-mail to a coworker, showing negative gestures, etc. (Blau \& Andersson, 2005; Martin \& Hine, 2005).

In the recent years most of the researchers have focused on consequences of incivility (Cortina et al., 2001; Estes \& Wang, 2008; Lim \& Teo, 2009; Pearson, Andersson, \& Porath, 2000). Andersson and Pearson (1999) argued that incivility rise or spirals as coworkers reciprocate uncivil behavior from fellows by responding with more intense forms of incivility like aggression. The initiative for such spirals is the violation and disobedience of a social norm of civility or respect, in which an employee perceives himself to be interpersonally mistreated by another employee. Therefore, low intensity aggression in the workplace can lead to an upward spiral, resulting in increased aggression and more purposeful efforts to harm one another (Pearson \& Porath, 2005). Interpersonal conflict is an organizational stressor involving incompatibility between employees (Spector \& Jex, 1998). Thus, we suggest that workplace incivility can lead toward interpersonal conflict.

Above literature indicates that

Hypothesis 4. Workplace incivility mediates the relationship between passive leadership and interpersonal conflict.

\section{FRAMEWORK} FIGURE 1

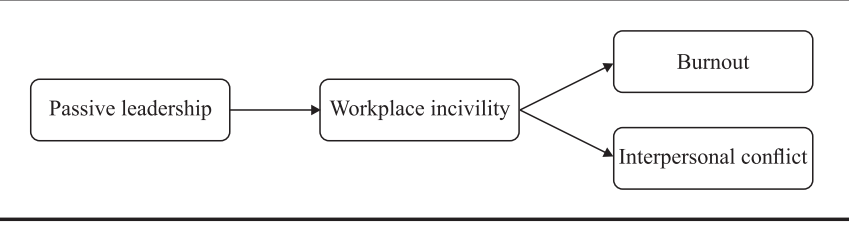

\section{RESEARCH METHODOLOGY}

Forthis study, theprimary datawasobtained frompublic sector employees in Pakistan. A total of 400 questionnaires were distributed to different departments of Government sector. The employees were given an orientation of the 
study, and were told that it was for scientific research purpose only; thus, ensured them of their anonymity and confidentiality. A 5-point Likert scale anchored by "strongly disagree" (1) to "strongly agree" (5) was used in cases of passive leadership, burnout and interpersonal conflict, while in the case of workplace incivility, a 5-point likert scale anchored by "Almost never" (1) to "Almost always"(5) was used. The questionnaires were personally given to the management, and they are requested to get these filled by their employees. The respondents were given adequate time to reply and responses were collected back at their convenient time. All participants had three weeks to fill these questionnaires and give them back. The questionnaires received were 284 (response rate $=71.2 \%$ ), but of those questionnaires, some were not usable. After omitting those questionnaires, we were left with 245 valid questionnaires, making the response rate as $61.25 \%$.

\section{Measures}

Eight items for passive leadership (employee reported) was used from the passive management-by-exception and laissez-faire subscales of the Multi-factor Leadership Questionnaire (MLQ) (Bass \& Avolio, 1997). It was used to measure the extent to which employees considered their leaders to exhibit passive behavior in the organizations. Sample items include: your leader, "Takes no action", "Avoids deciding", Delays responding". The internal consistency scale for this sample was 0.836 . This reliability is consistent with earlier studies in which they reported it as .80 to.90 range for this scale (e.g., Avolio, Bass, \& Jung, 1999; Druskat, 1994; Frooman, Mendelson, \& Murphy, 2012).

Moreover, a seven items scale of workplace incivility was adapted from a scale developed by Cortina etal. (2001). It measures the frequency of the coworkers and their colleagues to get involved in the uncivil behavior. Some of the examples from this scale includes: your coworkers "Addressed you in unprofessional terms, either publicly or privately," "Put you down or was condescending to you in some way" and "Ignored or excluded you from professional camaraderie." Initially coefficient alpha of this sample was 0.590 , then after removing two items, internal reliability consistency became 0.705 , which is consistent with previous estimates in the range of .70 to.95 (e.g., Chen, Ferris, Kwan, Yan, Zhou, \& Hong, 2013; Cortina et al., 2001; Ferguson, 2012).

Furthermore, burnout was adapted from a measure developed by Demerouti, Mostert, and Bakker (2010). It was used to measure the level of exhaustion that employees tolerate at their workplace. Examples include "During my work, I often feel emotionally drained", "There are the days when I feel tired before I arrive at work". This instrument included eight items; four of them were reverse based. Coefficient alpha of this sample was .923.
Additionally, five items from interpersonal conflict were adopted from Doucet et al. (2008), and were used to measure the conflict level of employees. Items included statements like "There are often differences in opinion regarding what should be done", "There are many conflicts relating to work ideas". The internal consistency reliability estimate was .803 .

\section{RESULTS}

\section{Correlation Analysis}

According to the table below (Table 1), the relationship between passive leadership and workplace incivility is significant $(\mathrm{r}=.239 * * * \mathrm{p}<.05)$, passive leadership and burnout is negatively correlated and insignificant $(\mathrm{r}=$ -.032), passive leadership and interpersonal conflict is also not significant $(\mathrm{r}=.038, \mathrm{p}<0.01)$, workplace incivility and interpersonal conflict is negatively correlated and significant, burnout and interpersonal conflict are positively and significantly correlated, and burnout and workplace incivility are significantly correlated.

\section{TABLE 1}

\section{Mean, Standard Deviation and Correlation}

\begin{tabular}{llllllll}
\hline & Variable & Mean & S.d. & $\mathbf{1}$ & $\mathbf{2}$ & $\mathbf{3}$ & $\mathbf{4}$ \\
\hline 1 & $\begin{array}{l}\text { Passive } \\
\text { leadership }\end{array}$ & 2.9597 & .428 & 1 & & & \\
2 & $\begin{array}{l}\text { Workplace } \\
\text { incivility }\end{array}$ & 2.6196 & .711 & $.239 * *$ & 1 & & \\
3 & Burnout & 3.0628 & .627 & -.032 & 0.00 & 1 & \\
4 & $\begin{array}{l}\text { Interpersonal } \\
\text { conflict }\end{array}$ & 3.3069 & .629 & .038 & $-.123^{*}$ & $.273^{* *}$ & 1 \\
\hline$* p$ & $<0.05, * * p$ & $<0.01$ & & & & &
\end{tabular}

TABLE 2

Result of Regression Analysis

\begin{tabular}{ccccccc} 
& & DV & & \multicolumn{2}{c}{ DV } \\
& Burnout & & \multicolumn{2}{c}{ Interpersonal conflict } \\
Predictors & $\boldsymbol{\beta}$ & $\mathbf{R}^{2}$ & $\Delta \mathbf{R}^{2}$ & $\boldsymbol{\beta}$ & $\mathbf{R}^{2}$ & $\Delta \mathbf{R}^{2}$ \\
\hline
\end{tabular}

Passive

leadership

Step 1

Control

Variable

Step 2

$\begin{array}{lllllll}\begin{array}{l}\text { Passive } \\ \text { leadership }\end{array} & -.050 & .022 & .001 & .062 & .023 & .002 \\ * p<.10 ; * * p<.05 ; * * * p<.01 & \end{array}$

\section{Regression Analysis}

According to Table 2, the direct relationship of 
passive leadership with burnout $(\beta=-.050, \mathrm{p}=0.248)$ and interpersonal conflict $(\beta=-.062, p=0.553)$ is not significant; thus, rejecting hypothesis 1 and 3 .

\section{Mediation Analysis}

After running regression tests, we used a simple process model: Model 4 (Hayes, 2013) specifying passive leadership as a predictor, workplace incivility as a mediator, and burnout and interpersonal conflict as outcome variables. Gender, tenure and qualification were entered as control variables. A bootstrapping method was used. Bootstrap method shows confidence intervals for estimating mediation analysis. Upper and lower limits of confidence interval constitutes a range that indicates an indirect effect if it does not overlap with zero. The $95 \%$ confidence interval shows that the result will hold true $95 \%$ of the time.

\section{Mediation analysis in case of Burnout}

According to the table below (Table 3), the total effect of passive leadership and burnout is insignificant, while passive leadership is positively and significantly associated with workplace incivility. Similarly, workplace incivility is positively associated with burnout. Further, the direct affect of passive leadership on burnout in the presence of workplace incivility is insignificant. Bootstrapped estimates (calculated across 5000 samples) suggests that passive leadership has a significant indirect effect on burnout $(95 \%$ CI $[-0.1869,-0.0553])$ through workplace incivility.

\section{Mediation Analysis in case of Interpersonal Conflict}

According to the table below (Table 4), passive leadership is positively and significantly associated with workplace incivility. Similarly, workplace incivility is positively associated with interpersonal conflict. Moreover, the direct effect of passive leadership on interpersonal conflict in the presence of workplace incivility is insignificant. Total effect of passive leadership and interpersonal conflict is insignificant. Bootstrapped estimates (calculated across 5000 samples) suggests that passive leadership has a significant indirect effect on interpersonal conflict $(95 \%$ CI $[-0.2,-0.1])$ through workplace incivility.

\section{DISCUSSION}

The main objective of the current study was to find out the role of passive leadership in determining the interpersonal conflict and burnout. Interestingly, the direct impact of passive leadership on burnout was not established in results. This is not consistent with previous studies that show the association between destructive leadership and burnout (Malloy \& Penprase, 2010; Corrigan et al. 2002). Similarly, passive leadership has no direct impact on interpersonal conflict as well, that are also inconsistent with prior studies (e.g., Einarsen, 1999). However, passive leadership affects these outcomes if workplace incivility plays a mediating role.

The apparent reason due to which passive leadership does not affect burnout and interpersonal conflict in public sector organizations can be explained in terms of life cycle theory which implies that when employees are unable and unwilling to do or to take responsibility for their job or task (Hersey \& Blanchard, 1969), then they are not concerned about what type of leadership behavior leaders are exhibiting, whether passive or active. As it is evident from the literature that public sector employees are considered to be ineffective, unable and unwilling (Kamoche , 1997), therefore, they don't care much about passive style of leader, and hence are not affected directly in terms of burnout and conflict with coworkers.

TABLE 3

Mediation Analysis in case of Burnout as outcome

\begin{tabular}{cccccc}
\hline $\begin{array}{c}\text { Effect of IV } \\
\text { On } \mathbf{M}\end{array}$ & $\begin{array}{c}\text { Effect of } \mathbf{M} \\
\text { on DV }\end{array}$ & $\begin{array}{c}\text { Direct Effect of } \\
\text { IV on DV in } \\
\text { Presence of } \mathbf{~ M ~}\end{array}$ & $\begin{array}{c}\text { Total effect of } \\
\text { IV on DV }\end{array}$ & \multicolumn{2}{c}{$\begin{array}{c}\text { Bootstrap results for } \\
\text { indirect effect }\end{array}$} \\
\hline .4122 & -.2696 & .0616 & .0 & LL 95 CI & UL 95 CI \\
\hline$I V=$ Passive leadership, $D V=$ Burnout, $M=$ workplace incivility, ${ }^{*} p=<0.1,{ }^{* *} p=<0.05, * * *=<0.01$
\end{tabular}

TABLE 4

Mediation Analysis in case of Interpersonal Conflict as outcome

\begin{tabular}{cccccc}
\hline $\begin{array}{c}\text { Effect of IV } \\
\text { On } \mathbf{M}\end{array}$ & $\begin{array}{c}\text { Effect of } \mathbf{M} \\
\text { on DV }\end{array}$ & $\begin{array}{c}\text { Direct Effect of } \\
\text { IV on DV in } \\
\text { Presence of } \mathbf{M}\end{array}$ & $\begin{array}{c}\text { Total effect of } \\
\text { IV on DV }\end{array}$ & \multicolumn{2}{c}{$\begin{array}{c}\text { Bootstrap results for } \\
\text { indirect effect }\end{array}$} \\
\hline 4 & -.1 & .1 & .0 & LL 95 CI & UL 95 CI \\
\hline$I V=$ Passive leadership, $D V=$ Interpersonal conflict, $M=$ workplace incivility, ${ }^{*} p=<0.1,{ }^{* *} p=<0.05, * * *=<0.01$
\end{tabular}


Moreover, when passive leaders avoid taking responsibilities and avoid resolving the disputes and incompetent in dealing with priorities (Bass, 2008), keeping themselves away from conflicts and trying to suppress discussions and good opinions are not valued (Gelfand et al., 2012), then followers who themselves are not mature enough as per life cycle theory (Hersey \& Blanchard, 1969), they take little negative effects of these behaviors. We can rather argue that employees in public sector organizations of Pakistan are more comfortable in working with passive leaders than transformational or any other type of positive leadership attributes. Thus, whenever in public sector organizations the leadership is passive, employees, contrary to findings in literature, won't be emotionally exhausted and will take no effect or involve in interpersonal conflict.

The other interesting finding of the study is that workplace incivility mediates the relationship. Since passive leaders lack control, are irresponsible, do not use authority, display unconcerned behavior, and are not caring at all about their employees' issues (Hamidifar, 2010); it give employees more room to exhibit workplace incivility. This can include answering the telephone in an impolite manner, talking negatively about another employee, and sending a rude e-mail to a coworker (Blau \& Andersson, 2005; Martin \& Hine, 2005), rude comments, thoughtless acts, or negative gestures (Keashly \& Jagatic, 2003; Neuman \& Baron, 1997). So, in the presence of uncivil behavior on routine basis, it will generate stress, exhaustion and burnout within their coworkers (Cortina et. a1, 2001).

Hickson et al., (2004) found that infrequent and irregulardecision-making processesaremorecharacterized in public organizations. Public sector therefore shows signs of the avoiding, uneven and political decisionmaking (Richard, 1982). Ultimately, employees will behave in the same passive manner, and avoid doing task, and engage themselves in uncivil behavior like gossiping and disrespecting others in the workplace. These activities will lead to interpersonal conflict.

Hence, because of the passive behavior of leaders, an eminent outcome is burnout and more conflicts within the organization, so passive leadership, directly, has no effect on burnout and interpersonal conflict, but when incivility mediates, it enhances burnout and interpersonal conflict.

\section{CONCLUSION}

Workplace incivility has major consequences for individuals within the organizations (Porath \& Pearson, 2013). The results of this research advocate that incivility is most probable to arise under the supervision of passive leaders, and workplace incivility is measured as an intervening variable that leads to burnout within employees and interpersonal conflict among co workers. We, therefore, believe the opinion of previous scholars (e.g., Aasland, Skogstad, Notelaers, Nielsen, \& Einarsen, 2010) that passive leadership is not just considered an absence of constructive behavior rather it is considered as a negative and destructive leadership. Once incivility creeps into a workplace, it can spread like a virus (Harold \& Holtz, 2014). Unless the management does not put the appropriate interventions, uncivil behavior can rapidly spill all over the workforce, and eventually impact an organization's well - being.

\section{REFERENCES}

Aasland, M. S., Skogstad, A., Notelaers, G., Nielsen, M. B., \& Einarsen, S. (2010). The prevalence of destructive leadership behaviour. British Journal of Management, 21(2), 438-452.

Alimo-Metcalfe, B., \& Alban-Metcalfe, J. (2004). Leadership in public sector organisations. Leadership in Organizations, 174.

Andersson, L. M., \& Pearson, C. M. (1999). Tit for tat? The spiraling effect of incivility in the workplace. Academy of Management Review, 24(3), 452-471.

Avolio, B. J., \& Bass, B. M. (1995). Individual consideration viewed at multiple levels of analysis: A multi-level framework for examining the diffusion of transformational leadership. The Leadership Quarterly, 6(2), 199-218.

Avolio, B. J., \& Gardner, W. L. (2005). Authentic leadership development: Getting to the root of positive forms of leadership. The Leadership Quarterly, 16(3), 315-338.

Avolio, B. J., Bass, B. M., \& Jung, D. I. (1999). Reexamining the components of transformational and transactional leadership using the Multifactor Leadership. Journal of Occupational and Organizational Psychology, 72(4), 441-462.

Barki, H., \& Hartwick, J. (2001). Interpersonal conflict and its management in information system development. Mis Quarterly, 195-228.

Bartlett, J. E., Bartlett, M. E., \& Reio Jr, T. G. (2008). Workplace Incivility: Worker and Organizational Antecedents and Outcomes. Online Submission

Bass, B. M. (1985). Leadership and performance beyond expectations. Free Press; Collier Macmillan.

Bass, B. M. (1991). From transactional to transformational leadership: Learning to share the vision. Organizational Dynamics, 18(3), 19-31.

Bass, B. M. (2008). Bass and Stogdill's handbook of leadership: Theory, research and managerial applications (Vol. 4). New York: Free Press.

Bass, B. M., \& Avolio, B. J. (1997). Full range leadership development: Manual for the Multifactor 
Leadership Questionnaire (pp. 43-44). Palo Alto, CA: Mind Garden.

Bass, B. M., \& Stogdill, R. M. (1990). Bass \& Stogdill's handbook of leadership: Theory, research, and managerial applications. Simon and Schuster.

Blau, G., \& Andersson, L. (2005). Testing a measure of instigated workplace incivility. Journal of Occupational and Organizational Psychology, 78(4), 595-614.

Brotheridge, C. M., \& Grandey, A. A. (2002). Emotional labor and burnout: Comparing two perspectives of "people work". Journal of Vocational Behavior, 60(1), 17-39.

Brown, P., \& Levinson, S. C. (1987). Politeness: Some universals in language usage (Vol. 4). Cambridge University Press.

Chen, Y., Ferris, D. L., Kwan, H. K., Yan, M., Zhou, M., \& Hong, Y. (2013). Self-love's lost labor: A self-enhancement model of workplace incivility. Academy of Management Journal, 56(4), 11991219.

Chênevert, D., Vandenberghe, C., Doucet, O., \& Ayed, A. K. B. (2013). Passive leadership, role stressors, and affective organizational commitment: A timelagged study among health care employees. Revue Européenne de Psychologie Appliquée/European Review of Applied Psychology, 63(5), 277-286.

Corrigan, P. W., Diwan, S., Campion, J., \& Rashid, F. (2002). Transformational leadership and the mental health team. Administration and Policy in Mental Health and Mental Health Services Research, 30(2), 97-108.

Cortina, L. M., Magley, V. J., Williams, J. H., \& Langhout, R. D. (2001). Incivility in the workplace: incidence and impact. Journal of Occupational Health Psychology, 6(1), 64.

Demerouti, E., Mostert, K., \& Bakker, A. B. (2010). Burnout and work engagement: a thorough investigation of the independency of both constructs. Journal of Occupational Health Psychology, 15(3), 209.

Doucet, O., Poitras, J., \& Chênevert, D. (2009). The impacts of leadership on workplace conflicts. International Journal of Conflict Management, 20(4), 340-354.

Druskat, V. U. (1994). Gender and leadership style: Transformational and transactional leadership in the Roman Catholic Church. The Leadership Quarterly, 5(2), 99-119.

Eid, J., Helge Johnsen, B., Bartone, P. T., \& Arne Nissestad, O. (2008). Growing transformational leaders: exploring the role of personality hardiness. Leadership \& Organization Development Journal, 29(1), 4-23.
Einarsen, S. (1999). The nature and causes of bullying at work. International Journal of Manpower, 20(1/2), 16-27.

Einarsen, S., Aasland, M. S., \& Skogstad, A. (2007). Destructive leadership behaviour: A definition and conceptual model. The Leadership Quarterly, 18(3), 207-216.

Eisenberger, R., Huntington, R., Hutchison, S., \& Sowa, D. (1986). Perceived organizational support. Journal of Applied Psychology, 71, 500-507

Estes, B., \& Wang, J. (2008). Workplace incivility: Impacts on individual and organizational performance. Human Resource Development Review.

Ferguson, M. (2012). You cannot leave it at the office: Spillover and crossover of coworker incivility. Journal of Organizational Behavior, 33(4), 571588

Friedman, R. A., Tidd, S. T., Currall, S. C., \& Tsai, J. C. (2000). What goes around comes around: The impact of personal conflict style on work conflict and stress. International Journal of Conflict Management, 11(1), 32-55.

Frooman, J., Mendelson, M. B., \& Kevin Murphy, J. (2012). Transformational and passive avoidant leadership as determinants of absenteeism. Leadership \& Organization Development Journal, 33(5), 447-463.

Gelfand, M. J., Leslie, L. M., Keller, K., \& de Dreu, C. (2012). Conflict cultures in organizations: How leaders shape conflict cultures and their organizational-level consequences. Journal of Applied Psychology, 97(6), 1131.

Gilbreath*, B., \& Benson, P. G. (2004). The contribution of supervisor behaviour to employee psychological well-being. Work \& Stress, 18(3), 255-266.

Gill, A. S., Flaschner, A. B., \& Shachar, M. (2006). Mitigating stress and burnout by implementing transformational-leadership. International Journal of Contemporary Hospitality Management, 18(6), 469-481.

Goldman, A. (2006). Personality disorders in leaders: Implications of the DSM IV-TR in assessing dysfunctional organizations. Journal of Managerial Psychology, 21(5), 392-414.

Gooty, J., Gavin, M., Johnson, P. D., Frazier, M. L., \& Snow, D. B. (2009). In the Eyes of the Beholder Transformational Leadership, Positive Psychological Capital, and Performance. Journal of Leadership \& Organizational Studies,15(4), 353-367.

Gouldner, A. W. (1960). The norm of reciprocity: A preliminary statement. American Sociological Review, 161-178. 
Hamidifar, F. (2010). A Study of the Relationship between Leadership Styles and Employee Job Satisfaction at IAU in Tehran, Iran. AU-GSB e-JOURNAL, 3(1).

Harold, C. M., \& Holtz, B. C. (2015). The effects of passive leadership on workplace incivility. Journal of Organizational Behavior, 36(1), 16-38.

Hayes, A. F. (2013). Introduction to mediation, moderation, and conditional process analysis: A regression-based approach. Guilford Press.

Hersey, P., \& Blanchard, K. H. (1969). Life cycle theory of leadership. Training \& Development Journal.

Hetland, H., Sandal, G. M., \& Johnsen, T. B. (2007). Burnout in the information technology sector: Does leadership matter?. European Journal of Work and Organizational Psychology, 16(1), 58-75.

Homans, G. C. (1958). Social behavior as exchange. American journal of sociology, 597-606.

Hooijberg, R., \& Choi, J. (2001). The impact of organizational characteristics on leadership effectiveness models an examination of leadership in a private and a public sector organization. Administration \& Society, 33(4), 403-431.

Jung, D. I., \& Avolio, B. J. (2000). Opening the black box: An experimental investigation of the mediating effects of trust and value congruence on transformational and transactional leadership. Journal of Organizational Behavior, 21(8), 949964.

Kamoche, K. (1997). Competence-creation in the African public sector. International Journal of Public Sector Management, 10(4), 268-278.

Kanste, O., Miettunen, J., \& Kyngäs, H. (2007). Psychometric properties of the Multifactor Leadership Questionnaire among nurses. Journal of Advanced Nursing, 57(2), 201-212.

Keashly, L., \& Jagatic, K. (2003). By any other name: American perspectives on workplace bullying. Bullying and emotional abuse in the workplace: International perspectives in research and practice, 31-61.

Kelloway, E. K., Sivanathan, N., Francis, L., \& Barling, J. (2005). 5 Poor leadership.

Krishnan, V. R., \& Arora, P. (2008). Determinants of transformational leadership and organizational citizenship behavior. Asia Pacific Business Review, 4(1), 34-43.

Lee, R. T., \& Ashforth, B. E. (1996). A meta-analytic examination of the correlates of the three dimensions of job burnout. Journal of Applied Psychology, 81(2), 123.

Leung, A. S. (2008). Interpersonal conflict and resolution strategies: An examination of Hong Kong employees. Team Performance Management: An International Journal, 14(3/4), 165-178.
Lim, V. K., \& Teo, T. S. (2009). Mind your E-manners: Impact of cyber incivility on employees' work attitude and behavior. Information \& Management, 46(8), 419-425.

Low, G. S., Cravens, D. W., Grant, K., \& Moncrief, W. C. (2001). Antecedents and consequences of salesperson burnout. European Journal of Marketing, 35(5/6), 587-611.

Malloy, T., \& Penprase, B. (2010). Nursing leadership style and psychosocial work environment. Journal of Nursing Management, 18(6), 715-725.

Martin, J. Miss Manners Rescues Civilization from Sexual Harassment: Frivolous Lawsuits. Dissing, and Other Lapses in Civility (New York, 1996), 149Martin149Miss Manners Rescues Civilization from Sexual Harassment: Frivolous Lawsuits, Dissing, and Other Lapses in Civility 1996.

Martin, R. J., \& Hine, D. W. (2005). Development and validation of the uncivil workplace behavior questionnaire. Journal of Occupational Health Psychology, 10(4), 477.

Maslach, C., \& Jackson, S. E. (1981). The measurement of experienced burnout. Journal of Occupational Behavior, 2(2), 99-113.

Maslach, C., Schaufeli, W. B., \& Leiter, M. P. (2001). Job burnout. Annual Review of Psychology, 52(1), 397-422.

McCranie, E. W., \& Brandsma, J. M. (1988). Personality antecedents of burnout among middle-aged physicians. Behavioral Medicine, 14(1), 30-36.

Miller, L., Reesor, K., McCarrey, M., \& Leikin, L. (1995). Nursing burnout. Employee Assistance Quarterly, 10(4), 29-52.

Miller, S., Wilson, D., \& Hickson, D. (2004). Beyond Planning:: Strategies for Successfully Implementing Strategic Decisions. Long Range Planning, 37(3), 201-218.

Morris, J. (1996). Democracy beguiled. The Wilson Quarterly, 24-35.

Moyer, D. (2008). Hothead habit.

Moynihan, D. P., \& Ingraham, P. W. (2004). Integrative Leadership in the Public Sector A Model of Performance-Information Use. Administration \& Society, 36(4), 427-453.

Neuman, J. H., \& Baron, R. A. (1997). Aggression in the workplace. Antisocial Behavior in Organizations, $37,67$.

Oetzel, J. G., \& Ting-Toomey, S. (2003). Face concerns in interpersonal conflict a cross-cultural empirical test of the face negotiation theory. Communication Research, 30(6), 599-624.

P. Greeff, Tanya De Bruyne, A. (2000). Conflict management style and marital satisfaction. Journal of Sex \& Marital Therapy, 26(4), 321-334. 
Pearson, C. M., \& Porath, C. L. (2004). On incivility, its impact, and directions for future research. The dark side of organizational behavior, 16, 403.

Pearson, C. M., \& Porath, C. L. (2005). On the nature, consequences and remedies of workplace incivility: No time for "nice"? Think again. The Academy of Management Executive, 19(1), 7-18.

Pearson, C. M., Andersson, L. M., \& Porath, C. L. (2000). Assessing and attacking workplace incivility. Organizational Dynamics, 29(2), 123-137.

Pearson, C. M., Andersson, L. M., \& Wegner, J. W. (2001). When workers flout convention: A study of workplace incivility. Human Relations, 54(11), 1387-1419.

Porath, C., \& Pearson, C. (2013). The price of incivility. Harvard Business Review, 91(1-2), 115-121.

Preacher, K. J., \& Hayes, A. F. (2008). Asymptotic and resampling strategies for assessing and comparing indirect effects in multiple mediator models. Behavior Research Methods, 40(3), 879-891.

Rahim, M. A., Garrett, J. E., \& Buntzman, G. F. (1992). Ethics of managing interpersonal conflict in organizations. Journal of Business Ethics, 11(5-6), 423-432.

Reio, T. G., \& Ghosh, R. (2009). Antecedents and outcomes of workplace incivility: Implications for human resource development research and practice. Human Resource Development Quarterly, 20(3), 237-264.

Richard E. Boyatzis. (1982). The competent manager: A model for effective performance. John Wiley \& Sons.

Roberts, S. J., Scherer, L. L., \& Bowyer, C. J. (2011). Job stress and incivility: What role does psychological capital play?. Journal of Leadership \& Organizational Studies, 1548051811409044.

Schaufeli, W. B., \& Bakker, A. B. (2004). Job demands, job resources, and their relationship with burnout and engagement: A multi-sample study. Journal of Organizational Behavior, 25(3), 293-315.

Schaufeli, W., \& Enzmann, D. (1998). The burnout companion to study and practice: A critical analysis. CRC press.

Shamir, B., House, R. J., \& Arthur, M. B. (1993). The motivational effects of charismatic leadership: A self-concept based theory. Organization Science,4(4), 577-594.

Sosik, J. J., \& Godshalk, V. M. (2000). Leadership styles, mentoring functions received, and jobrelated stress: a conceptual model and preliminary study. Journal of Organizational Behavior, 21(4), 365-390.

Spector, P. E., \& Jex, S. M. (1998). Development of four self-report measures of job stressors and strain: Interpersonal Conflict at Work Scale, Organizational Constraints Scale, Quantitative Workload Inventory, and Physical Symptoms Inventory. Journal of Occupational Health Psychology, 3(4), 356.

Thibault, J. W., \& Kelley, H. H. (1959). Social Exchange Theory.

Thibaut, J. W., \& Kelley, H. H. (1959). The social psychology of groups.

Thomas, C. H., \& Lankau, M. J. (2009). Preventing burnout: The effects of LMX and mentoring on socialization, role stress, and burnout. Human Resource Management, 48(3), 417-432.

Ting-Toomey, S., \& Takai, J. (2006). Explaining intercultural conflict: Promising approaches and directions. The Sage Handbook of Conflict Communication, 691-723.

Wall, J. A., \& Callister, R. R. (1995). Conflict and its management. Journal of Management, 21(3), 515558.

Wart, M. V. (2003). Public-Sector leadership theory: An assessment. Public Administration Review, 63(2), 214-228.

Yankelovich, D. (1991). Coming to public judgment: Making democracy work in a complex world. Syracuse University Press.

Yeung, A., \& Griffin, B. (2008). Workplace Incivility: Does it Matter in Asia? People and Strategy, 31(3), 14. 